\title{
Cutaneous nocardiosis: an underdiagnosed pathogenic infection
}

\author{
Sathish Pai, Kanthilatha Pai, Swati Sharma
}

Department of Dermatology and Pathology, Kasturba Medical College, Manipal University, Manipal, India

\section{Correspondence to}

Dr Kanthilatha Pai,

klpai@yahoo.com

Accepted 30 January 2015

\section{DESCRIPTION}

A 35-year-old woman presented with raised red lesions over the elbow at the site of a prior injury from a road traffic accident which had occurred 3 years ago. She gave history of pus discharge from the lesions occasionally. A previous biopsy suggested a diagnosis of cutaneous botryomycosis following which the patient received a course of antibiotics for a week. A culture revealed no bacterial or fungal growth. But the lesions continued to progress with pus drainage. On clinical examination, multiple skin-coloured nodules with erosions and crusting were seen over the extensor aspect of the elbow around the site of prior scar (figure 1). Systemic examination was normal. A clinical differential diagnosis of actinomycosis, deep mycoses and cutaneous tuberculosis was made. On histopathological examination, multiple basophilic colonies surrounded by neutrophilic abscesses and granulation tissue with dense infiltration by acute and chronic inflammatory cells were seen (figure 2). These colonies were Periodic acid-Schiff (PAS) positive, weakly Gram positive and methanamine silver positive. Acid-fast stain using $1 \%$ sulfuric acid showed fine, beaded filaments with right-angled branching (figure 3). The bacterial and fungal cultures reported negative. A diagnosis of cutaneous nocardiosis was suggested based on the morphology and the staining properties on biopsy. The patient was started on treatment with amoxycillin and clavulinic acid $1 \mathrm{~g}$ twice daily for 6 months. She has now completed 2 months of treatment, has

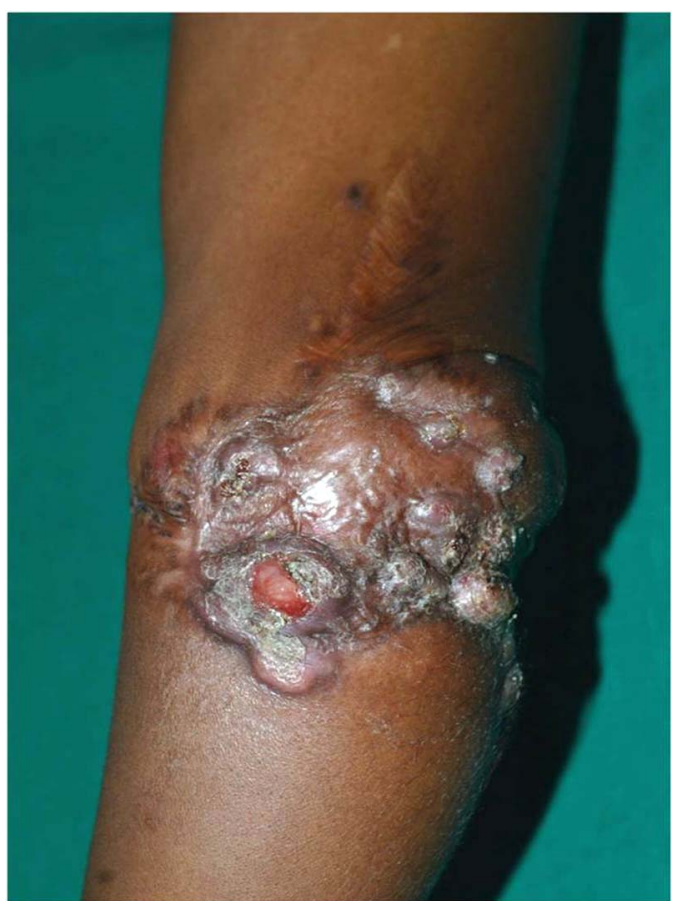

Figure 1 Clinical picture showing multiple nodules with erosions and crusting over the elbow.

reported significant improvement and is due for a follow-up visit.

Primary cutaneous nocardiosis remains a diagnostic challenge as there are no characteristic
To cite: Pai $\mathrm{S}$, Pai $\mathrm{K}$ Sharma S. BMJ Case Rep Published online: [please include Day Month Year] doi:10.1136/bcr-2014208713

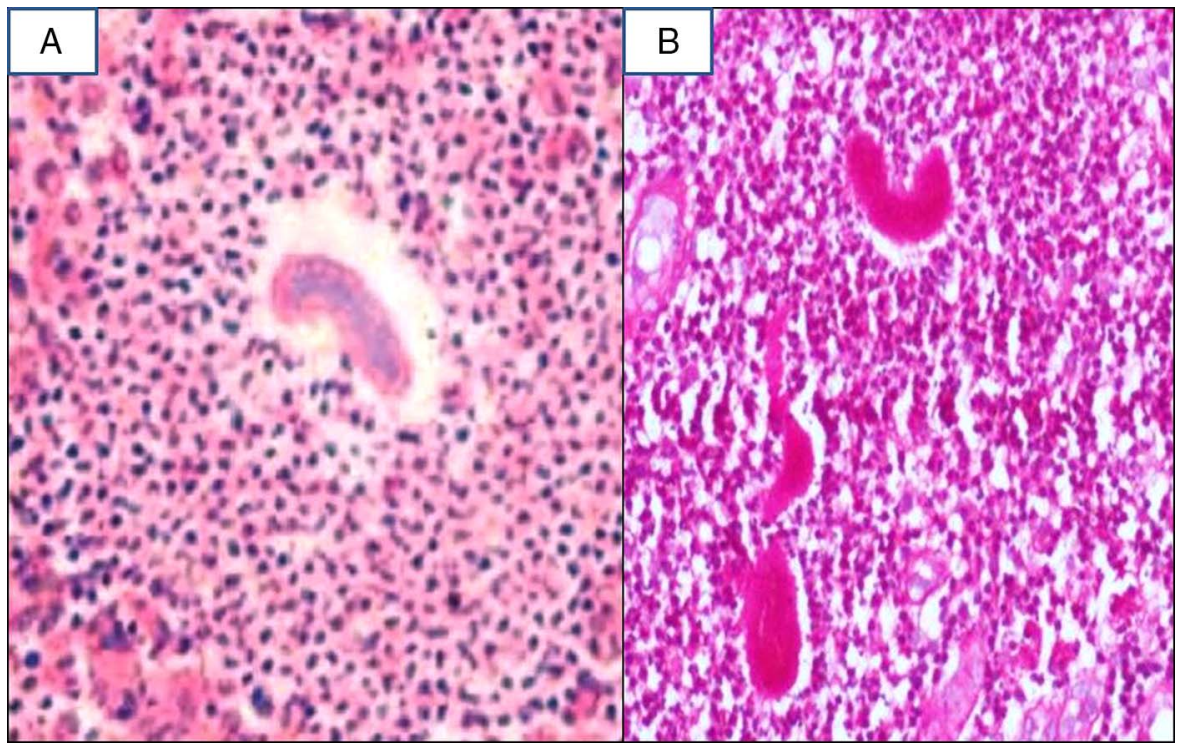

Figure 2 Photomicrograph A and B showing fine filamentous bacteria surrounded by neutrophilic abscess on H\&E and Periodic acid-Schiff staining, respectively. 


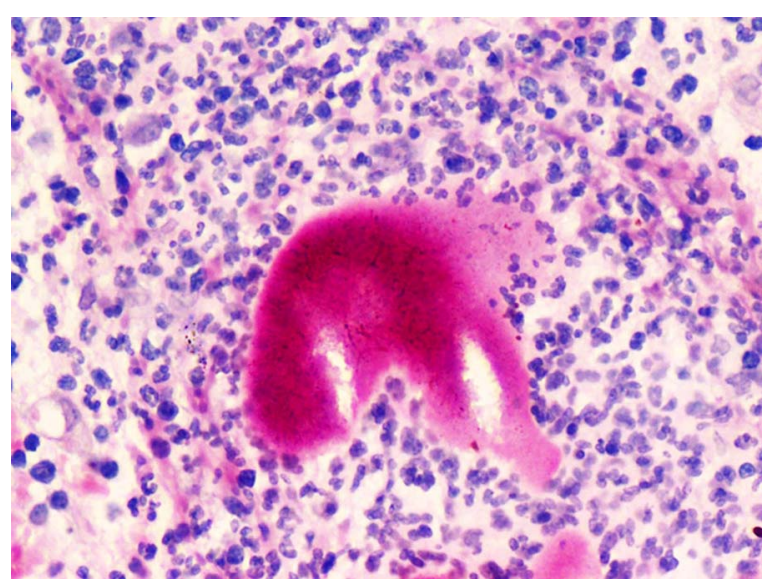

Figure 3 Photomicrograph showing fine, beaded filamental organisms on modified acid-fast stain.

features to help make a definitive clinical diagnosis possible. ${ }^{1}$ Delay in establishing the correct diagnosis occurs frequently due to the non-specific and diverse clinical presentation of nocardiosis and the inherent difficulty in cultivating Nocardia. Demonstration of the organism from clinical specimens by Gram stain and modified acid-fast stain is the mainstay of diagnosis. $^{2}$ Gram positive and acid fast, thin, beaded, branching filaments are the characteristic appearance of the organism. The diagnosis of nocardiosis is often missed in culture as nocardiosis requires 1-2 weeks before well-sized colonies are formed. It is hence often reported as no growth after $48 \mathrm{~h}$ and the cultures are discarded, as in our case. ${ }^{3}$

\section{Learning points}

- Nocardia infection should be suspected in trauma-associated cutaneous infections poorly responding to routine treatment.

- The dermatologist's specific vigilance is crucial to alert pathologists or microbiologists towards the differential diagnosis of cutaneous nocardiosis.

- Long term treatment with antibiotics for a course of 6 months is necessary to treat Nocardiosis.

\section{Competing interests None.}

\section{Patient consent Obtained.}

Provenance and peer review Not commissioned; externally peer reviewed.

\section{REFERENCES}

1 Brown-Elliott BA, Brown JM, Conville PS, et al. Clinical and laboratory features of the Nocardia spp. based on current molecular taxonomy. Clin Microbiol Rev 2006; 19:259-82.

2 Vyas MCR, Arora HL, Joshi KR. Histopathological identification of various causal species of mycetoma prevalent in North-West Rajasthan. Indian J Dermato/ Venereol Leprol 1985;51:76-9.

3 McNeil MM, Brown JM. The medically important aerobic actinomycetes: epidemiology and microbiology. Clin Microbiol Rev 1994;7:357-417.

Copyright 2015 BMJ Publishing Group. All rights reserved. For permission to reuse any of this content visit http://group.bmj.com/group/rights-licensing/permissions.

BMJ Case Report Fellows may re-use this article for personal use and teaching without any further permission.

Become a Fellow of BMJ Case Reports today and you can:

- Submit as many cases as you like

- Enjoy fast sympathetic peer review and rapid publication of accepted articles

- Access all the published articles

- Re-use any of the published material for personal use and teaching without further permission

For information on Institutional Fellowships contact consortiasales@bmjgroup.com

Visit casereports.bmj.com for more articles like this and to become a Fellow 